PEMBELAJAR: Jurnal Ilmu Pendidikan, Keguruan, dan Pembelajaran

Volume 2 Nomor 2 Oktober 2018 Hal. $101-109$

e-ISSN: 2549-9114 dan p-ISSN: 2549-9203

(Received: April-2018; Reviewed: September-2018; Published: Oktober 2018)

DOI: http://dx.doi.org/10.26858/pembelajar.v2i2.5760

\title{
Kekuatan Kognitif Siswa Tunagrahita Ringan Terhadap Kegiatan Pembelajaran Keterampilan Budidaya Hortikultura
}

\author{
Ning Suryani ${ }^{\mathrm{a}}$,Mumpuniarti ${ }^{\mathrm{a}}$ \\ aPendidikan Luar Biasa, Fakultas Pascasarjana, Universitas Negeri Yogyakarta \\ Corresponding e-mail: ningsuryani0193@gmail.com
}

\begin{abstract}
Abstrak: Siswa tunagrahita ringan memiliki kemampuan intelektual (kognitif) yang rendah dan mengalami hambatan perilaku adaptif. Kemampuan tersebut mempengaruhi kemampuan tunagrahita dalam bidang vokasional keterampilan pertanian budidaya hortikultura. ujuan penelitian ini untuk mengetahui kekuatan kognitif anak tunagrahita ringan dalam melakukan kegiatan keterampilan budidaya hortikultura. Partisipan pada penelitian ini terdiri dari 3 siswa tunagrahita ringan dengan rentang usia 8-12 tahun. Data penelitian ini dikumpulkan melalui 3 (tiga) teknik pengumpulan data yaitu tes, observasi dan wawancara. Analisis data dilakukan dengan metode deskriptif kuantitatif. Hasil yang diperoleh dari penelitian ni menunjukkan bahwa kemampuan kognitif anak mencapai skor tertinggi dengan nilai 7 pada konsep sains sederhana (kemampuan kognitif lengkap). Kemampuan kognitif belum lengkap dengan skor 6 pada pengetahuan bentuk geometri, pengetahuan ukuran baku/tidak baku dan pengetahuan konsep waktu, skor 5 pada kemampuan mengenal benda di sekitarnya, skor 4 pada konsep bilangan 0-50 dan kemampuan menyelesaikan masalah sederhana. Skor terendah 2 pada kemampuan pengetahuan konsep urutan (belum memiliki kemampuan kognitif pada aspek tersebut). Berdasarkan hasil penelitian ini, diketahui bahwa anak tunagrahita ringan belum memiliki kognitif yang lengkap dalam kegiatan keterampilan budidaya hortikultura, sehingga membutuhkan penguatan dan latihan.
\end{abstract}

Kata kunci: tunagrahita ringan, kognitif, keterampilan budidaya hortikultura

\begin{abstract}
Intellectual disability students have an impairment of intellectual (cognitive) abilities and experience barriers to adaptive behavior. This ability affects their capability in vocational agricultural skills of horticultural cultivation. The purpose of this research is to know the cognitive strength of children with mild mental retardation/intellectual disability in conducting horticulture cultivation skills. Participants in this study consisted of 3 mild mental retardation/intellectual disability students, age between 8 to 12 years old. The data of this study are collected through 3 (three) data collecting technique i.e. test, observation and interview. Data analysis was done by quantitative descriptive method. The results obtained from this study indicate that the cognitive abilities of children achieve the highest score of 7 on the simple science concept (complete cognitive ability). Cognitive ability is incomplete with score 6 on geometric knowledge, knowledge of standard / non-standard size and timeconcept knowledge, score 5 on the ability to recognize the surrounding objects, score 4 on the number concept of $0-50$ and the ability to solve simple problems. The lowest score is 2 on the ability of sequence number concept i.e. they have not had cognitive ability on that aspect yet. Based on the results of this study, it is known that children with mild mental retardation/intellectual disability do not have complete cognitive in horticultural cultivation skills activities, thus requiring reinforcement and skill training.
\end{abstract}

Keywords: Student with Intellectual Disabilitie, kognitif, horticulture cultivation 


\section{PENDAHULUAAN}

Keterampilan pertanian budidaya hortikultura cukup penting bagi bekal kehidupan setiap manusia, termasuk bagi anak tunagrahita. Kemampuan bertani bagi tunagrahita ini diharapkan dapat dijadikan suatu usaha yang dapat menghasilkan sesuatu bagi kehidupannya. Kemampuan tersebut diharapkan dapat memperluas kesempatan tunagrhaita untuk dapat hidup mandiri di tengah kehidupan masyarakat. Kemampuan bertani dirasakan penting dikarenakan negara Indonesia sebagai negara agraris sehingga keterampilan bertani yang memegang peranan penting dalam perekonomian nasional. Selain itu, keterampilan bertani merupakan salah satu cara untuk bertahan hidup yang bisa dilakukan semua orang, baik itu orang yang ekonominya di atas rata-rata maupun di bawah rata-rata. Kegiatan bertani disini diartikan sebagai upaya manusia terhadap proses pengendalian produk biologis yang terjadi di alam, mencakup pengendalian pertumbuhan tanaman, peternakan dan perikanan (Nurmala, 2012: 3). Beberapa hal yang harus diperhatikan dalam keterampilan bertani, diantaranya iklim, tanah, aturan atau cara kegiatan bertani seperti pengolahan tanah, pembibitan, penanaman, dan pemungutan hasil tani. Pendidikan keterampilan pertanian terbukti mampu menjadi salah satu keterampilan yang memandirikan anak berkebutuhan khusus (Ira Ariyanti, Juang Sunanto \& Ahmad Nawawi, 2015: 1). Pendidikan keterampilan vokasional keterampilan pertanian penting untuk kemandirian tunagrahita, dan harus didukung oleh pendidikan akademik (Tin Suharmini, 2007: 70).

Kenyataan di lapangan menunjukkan bahwa program pendidikan pada peserta didik tungrahita saat ini masih sangat menekankan kepada aspek pengajaran yang bersifat akademik, itupun dalam pelaksanaanya masih bersifat klasikal dan belum memperhitungkan perbedaan hambatan belajar dan kebutuhan yang dialami anak secara individual (Alimin, 2006: 1). Padahal sekolah seharusnya mengembangkan program-program yang terkait langsung dengan kehidupan anak di lingkungannya. Hasil penelitian tersebut dikuatkan hasil Data Survei Sosial Ekonomi Nasional (SUSENAS) tahun 2013 mencatat tunagrahita berumur 15 tahun ke atas hanya $37,85 \%$ memiliki pekerjaan, serta $51,41 \%$ bekerja di bidang pertanian. Hasil penelitian Een Ratnengsih (2017: 89-90) menunjukkan bahwa sekitar $40 \%$ anak tunagrahita memperoleh pendidikan formal (SLB Negeri/Swasta), dan SLB yang melaksankan program pertanian $7 \%$. Berdasarkan data tersebut terlihat adanya kesenjangan antara kebutuhan keterampilan pertanian tunagrahita pasca sekolah dengan layanan pendidikan yang diprogramkan sekolah. Data tersebut juga menunjukkan bahwa pendidikan yang telah diikuti tunagrahita belum memberikan pengaruh yang nyata untuk kemandirian vokasional terhadap kehidupannya. Sekolah seharusnya menyediakan program belajar yang sesuai dengan kebutuhan peserta didik, menyiapkan peserta didik menjadi mandiri setelah selesai menempuh pendidikan SLB.

Pendidikan akademik diperlukan tunagrahita untuk mengembangkan kemampuan kognitif dengan tujuan pendukung bagi keterampilan menolong diri dan kemandiriannya, maka program yang dirancang harus mengacu pada tugas perkembangan, dan mempersiapkan peserta didik untuk mandiri dan bekerja di masyarakat (Mumpuniarti, 2007: 138). Mengacu Peraturan Menteri Pendidikan Dan Kebudayaan Republik Indonesia Nomor 40 Tahun 2014 Tentang Kerangka Dasar Dan Struktur Kurikulum Sekolah Menengah Atas Luar Biasa, muatan isi kurikulum 2013 satuan pendidikan SMPLB terdiri atas 40\%aspek akademik dan $60-70 \%$ berisi aspek keterampilan vokasional. Alternatif keterampilan vokasional yang dicantumkan dalam Kompetensi Dasar Prakarya SMPLB Kurikulum 2013, adalah program pertanian, dengan materi mengenal proses pembenihan, membesarkan, memodifikasi media, memperbanyak tanaman sayur, dan mengenal proses pembuatan aneka pupuk. Standar kompetensi (SK) dan kompetensi dasar (KD) pelajaran yaitu: 1) mengenal alat dan bahan pertanian serta kegunaannya; 2) mengenal tanah yang memenuhi persyaratan tumbuh tanaman sayuran; 3) mengenal aneka tanaman sayuran lokal yang bisa dibudidayakan secara organik; 4) membudidayakan tanaman hortikultura secara organik; 5) melakukan panen dan pasca panen; dan 6) memperhatikan keselamatan kerja. Kompetensi tersebut dapat tercapai salah satunya melalui program pembelajaran keterampilan pertanian budidaya hortikultura. Pembelajaran keterampilan pertanian budidaya 
hortikultura ini bertujuan untuk menstimulasi dalam mengoptimalkan kemampuan kognitif dan melatih keterampilan vokasional tunagrahita.

Tunagrahita merupakan kondisi kompleks, yang ditandai dengan kemampuan intelektual (kognitif) rendah dan mengalami hambatan dalam perilaku adaptif (Dunn \& Leitschuch, 2014: 491). Polloway Edward A \& Patton James R(1993: 56) mengatakan seorang anak mengalami hambatan mental jika pada aspek belajar, social, dan pola perilaku yang ditunjukkan mengalami keterbatasan dan terjadi pada periode waktu yang lama. Menurut Hallahan (2009: 149), berdasarkan ukuran tingkat inteligensinya, tunagrahita ringan memiliki IQ 70-75. Mereka yang termasuk dalam kelompok ini meskipun kecerdasan dan adaptasi sosialnya terhambat, namun mempunyai kemampuan untuk berkembang dalam bidang pelajaran akademik (kognitif), penyesuaian sosial dan kemampuan bekerja.

Guru dalam kegiatan pembelajaran pada anak tunagrahita ringan perlu memperhatikan tahapan perkembangan mereka dan melibatkan anak tunagrahita aktif didalamnya, menciptakan suasana belajar yang menyenangkan, mempermudah siswa dalam menerima materi yang disampaikan dan untuk kepentingan itu dibutuhkan media sebagai alat pembelajaran. Sebagian besar pembelajaran di sekolah selalu berhubungan dengan mengingat dan berpikir yang termasuk ke dalam aktivitas kognitif, dimana faktor perkembangan kognitif merupakan peran penting bagi keberhasilan anak dalam belajar. Oleh karena itu, seorang guru dalam pembelajaran terlebih-lebih pada anak tunagrahita ringan sebaiknya materi yang diberikan disesuaikan dengan tahap perkembangan kognitifnya. Sebagaimana diungkapkan oleh Abdurrahman (2003: 255) bahwa "Kemampuan kognitif dan segala sesuatu yang terkait dengan berpikir berbeda-beda untuk tiap tahap perkembangannya, maka guru harus menyesuaikan bahan pelajaran dengan tahap perkembangan anak".

Mumpuniarti (2007: 139) menyatakan prinsip pembelajaran yang berimplikasi pada pembelajaran siswa tunagrahita ringan di antaranya suatu program hendaknya disusun dari tahapan yang sederhana menuju yang lebih kompleks. Belajar hendaknya dilakukan secara aktif, sehingga dapat berjalan secara efektif dan efisien. Memberikan penguat secara langsung ketika siswa menunjukkan respon yang diharapkan. Program hendaknya menyiapkan pengajaran yang bersifat individual, sehingga siswa mampu belajar sesuai dengan kemampuannya. Evaluasi yang konsisten dilakukan guna memperoleh refleksi setiap materi pengajaran sehingga dapat memberikan catatan agar diperoleh cara yang efektif dan efisien. Materi yang ditetapkan hendaknya mendukung dalam pencapaian tujuan khusus yang telah ditetapkan. Materi yang disampaikan dalam batas-batas kemampuan dan bermanfaat bagi siswa. Materi disajikan dari yang mudah ke yang sukar, dari yang sederhana ke yang kompleks dan dari yang konkret ke yang abstrak. A. Salim Choiri dan Ravik Karsidi dalam Sugiyartun (2009: 30) menyatakan bahwa anak tunagrahita ringan, ketika dihadapkan pada kemampuan kognitif dasar akan menjadi abstrak jika gurunya memberikan pembelajaran tanpa suatu alat bantu media pembelajaran, maka dari itu dalam pembelajaran terhadap anak tunagrahita diperlukan sebuah media pembelajaran yang dapat menunjang proses pembelajaran mereka.

Keterbatasan mental tunagrahita juga berakibat pada kemampuan kognitif. Kemampuan itu masih bisa dioptimalkan jika diberikan intervensi khusus. Eldevik, et.al. (2010) menemukan bahwa intervensi khusus pada siswa yang kecerdasan rendah dapat bermanfaat. Intervensi khusus ini terkait taraf usia mental yang dicapai lebih rendah dengan rerata siswa umumnya. Hal itu dalam pembelajaran lebih tepat dengan strategi pembelajaran melalui benda konkrit dan situasi pembelajaran yang menyenangkan. Aktivitas pada saat keterampilan budidaya hortikultura dapat digunakan sebagai sarana mengoptimalkan kognitifnya, seperti hasil penelitian Wakiman, (1998: 212) yang menyebutkan suasana kelas yang menyenangkan dapat menimbulkan minat belajar. Diharapkan dengan kegiatan keterampilan budidaya hortikultura sesuai tingkat perkembangan anak akan mampu menggairahkan suasana belajar dan mengoptimalkan kognitif tunagrahita. Hal itu ditandaskan oleh Hallahan \& Kauffman (2003: 131) bahwa anak-anak yang kategori retardasi mental/tunagrahita diajarkan akademik untuk kemandirian yang disebut dengan akademik fungsional.

Kemandirian dalam kehidupan seharihari perlu dilatihkan pada anak berkebutuhan 
khusus. Keterampilan hidup termasuk pembelajaran utama bagi seorang anak berkebutuhan khusus, karena dengan menguasai keterampilan hidup, seseorang tidak lagi bergantung kepada orangtua dalam memenuhi kebutuhan hidupnya sehari-hari (Putri \& Murtiningsih, 2013: 157). Aktivitas dalam kehidupan sehari-hari berkaitan dengan keterampilan hidup, hal tersebut juga dikemukakan oleh Ayres, Mechling \& Sansosti (2013: 260), bahwa ketrampilan hidup merupakan keterampilan yang dibutuhkan untuk mewujudkan kehidupan sehari-hari yang produktif. Kemandirian ketrampilan hidup sehari-hari dapat dicapai oleh setiap individu termasuk anak tunagrahita ringan apabila memiliki kognitif yang sesuai dengan lingkungannya. Namun, saat ini masih minim penelitian yang mengkaji tentang optimalisasi kognitif pada anak tunagrahita ringan untuk menunjang kemandiriannya. Oleh karena itu, perlu adanya penelitian tentang optimalisasi kognitif pada anak tunagrahita ringan yang sekaligus bermanfaat untk melatih keterampilan vokasionalnya. Tujuan penelitian ini untuk mengetahui kekuatan kognitif anak tunagrahita ringan dalam melakukan kegiatan keterampilan budidaya hortikultura.

\section{METODE}

\subsection{Pendekatan}

Penelitian ini menggunakan jenis penelitian deskriptif dengan pendekatan kuantitatif. Penelitian deskriptif merupakan penelitian yang mengungkapkan kejadian sebenarnya. Menurut Sugiyono (2012: 13) penelitian deskriptif yaitu, penelitian yang dilakukan untuk mengetahui nilai variabel mandiri, baik satu variabel atau lebih (independen) tanpa membuat perbandingan, atau menghubungkan dengan variabel yang lain. Berdasarkan teori tersebut, penelitian deskriptif kuantitatif, merupakan data yang diperoleh dari sampel populasi penelitian dianalisis sesuai dengan metode statistik yang digunakan.

\subsection{Tempat dan Subyek Penelitian}

Penelitian dilaksanakan di SLB Wiyata Dharma 1 Sleman. Subjek dipilih berdasarkan teknik purposive sampling: tiga siswa tunagrahita ringan jenjang SMP LB. Kriteria siswa tunagrahita ringan dipilih karena tunagrahita yang masih memiliki potensi untuk dioptimalkan kognitifnya adalah tunagrahita ringan.

\subsection{Teknik Pengumpulan Data}

Teknik pengumpulan data menggunakan teknik tes, observasi dan wawancara. Tes adalah metode pengumpulan data yang digunakan untuk menguji pengetahuan subjek penelitian (Borg and Gall, 2007: 214). Tes digunakan untuk mengetahui tingkat pengetahuan (kekuata kognitif) yang dimiliki subjek pada pembelajaran keterampilan. Tes dilakukan dengan tes kinerja kemampuan kognitif siswa ditinjau dari berbagai aktivitas yang berbeda sesuai dengan kebutuhan khusus setiap siswa. Observasi dilakukan dengan teknik observasi partisipan, sehingga peneliti terlibat langsung pada aktivitas yang dilakukan siswa agar aktivitas yang dimunculkan terjadi secara alami. Menurut Wina Sanjaya (2013: 77), observasi partisipasif adalah observasi yang dilakukan observer dengan terjun langsung pada kegiatan (observer adalah bagian dari kegiatan). Peneliti mencatat berbagai aktivitas yang berhubungan dengan kemampuan kognitif yang ditunjukkan siswa. Observasi dilakukan peneliti pada saat siswa tunagrahita SMPLB melakukan praktek keterampilan budidaya tanaman sayur. Wawancara adalah metode pengumpulan data yang digunakan untuk mengungkap informasi dari subjek secara lisan (Borg and Gall, 2007: 246). Wawancara dilakukan pada orang tua dan guru, dilakukan secara terstruktur, sehingga wawancara terarah sesuai dengan pedoman yang ada

\subsection{Teknik Analisis Data}

Analisis data pada penelitian ini dilakukan dengan teknik analisis data deskriptif kuantitatif. Data hasil wawancara dan observasi dianalisis sebagai data pelengkap untuk menggambarkan mengenai kemampuan kognitif pada anak. Data yang telah dianalisis akan dimaknai dengan kategori untuk mengetahui pola kemampuan kognitif siswa tunagrahita ringan.

\section{HASIL DAN PEMBAHASAN}

\subsection{Hasil Penelitian}

Hasil dari analisis deskripsi kekuatan kognitif pada anak tunagrahita ringan dalam aktivitas keterampilan budidaya hortikultura 
dapat dijelaskan sebagai berikut. Terdapat delapan area aktivitas yang diteliti untuk mengetahui kekuatan kognitif yaitu 1) mengenali benda di sekitarnya (lingkungan budidaya tanaman hortikultura) menurut bentuk, jenis, dan ukuran; 2) mengenal konsep sains sederhana dengan obyek lingkungan pertanian; 3) mengenal bilangan 0-50 dan operasionalnya; 4) mengenal konsep urutan/pola; 5) mengenal konsep bentuk geometri matematika sederhana; 6) mengenal ukuran baku dan tidak baku; 7) mengenal konsep waktu perawatan tanaman; 8) menyelesaikan masalah sederhana misalnya menyelesaikan masalah hama penyakit tanaman (HPT). Hasil penelitian pada setiap area tersebut telah menunjukkan kemampuan atau kekuatan kognitif seperti memiliki kognitif yang lengkap, sebagian dan belum memiliki kognitif untuk keterampilan prtanian. Setiap aspek tersebut masih terdapat poin-poin yang lebih spesifik yang diteliti sehingga penelitian ini telah mencakup aspek-aspek yang ada dalam budidaya hortikultura. Penelitian ini dilakukan pada tiga anak tunagrahita dan hasil ketiga anak tersebut digabungkan menjadi satu. Hasil penelitian ini, diwujudkan dalam grafik 1 (pembulatan nilai lebih dari 0,5 dibulatkan ke nilai diatasnya, misal 3,6 menjadi 4).

Dari grafik tersebut dapat dimaknai bahwa anak tunagrahita ringan jenjang SMP LB memiliki kemampuan kognitif terhadap budidaya hortikultura bervariasi. Tunagrahita ringan pada subyek penelitian memiliki kognitif lengkap pada kemampuan mengenal konsep sains sederhana dengan skor 7. Kemampuan kognitif yang belum lengkap pada kemampuan mengenal konsep bilangan 0-50 dan menyelesaikan masalah sederhana dengan skor 4, mengenal bentuk ukuran baku/tidak baku, bentuk geometri dan konsep waktu masingmasing dengan skor 6. Kemampuan kognitif dalam konsep urutan memiliki skor paling rendah dengan nilai 2 , artinya tunagrahita ringan pada subyek penelitian belum memiliki kemampuan kognitif dalam aspek tersebut. Dari data yang diperoleh diatas, dapat disimpulkan bahwa anak tunagrahita masih memerlukan peningkatan dalam kemampuan kognitif dalam 7 aspek dengan kriteria kemampuan kognitif yang belum lengkap dan belum memiliki kemampuan kognitif. Hanya pada aspek konsep sains sederhana yang memiliki kriteria kemampuan kognitif lengkap.
Dari hasil penelitian tersebut, dapat dilihat bahwa siswa tunagrahita ringan memiliki keterbatasan kognitif tentang pengetahuan yang harus dimiliki untuk melakukan aktivitas keterampilan budidaya hortikultura.

Grafik 1. Kemampuan kognitif tunagrahita ringan terhadap aktifitas budidaya hortikultura

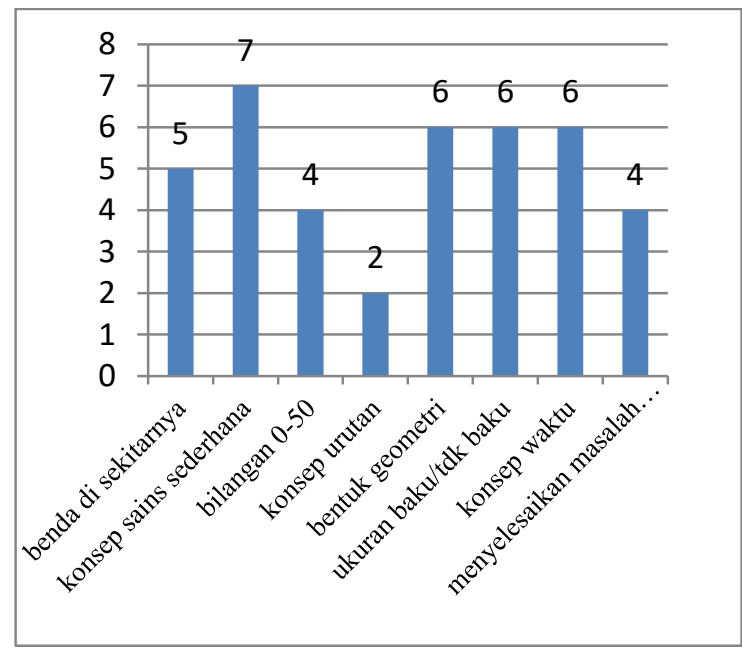

\subsection{Pembahasan}

Siswa tunagrahita ringan yang mendapat perlakuan dalam tindakan ini berjumlah tiga orang dengan kode Sn, Hn, dan Au. Siswa berkode Au adalah siswa putra, dengan kondisi tunarungu tunagrahita, mudah diajak komunikasi jika muka berhadapan lurus. Siswa berkode Hn adalah siswa putra, sedikit lancar berbicara, dan belum lancar membaca. Siswa berkode Sn adalah siswa putri dengan kemampuan bicara gagap, belum lancar membaca, namun tekun saat melakukan pemilihan biji-bijian.

Tahap dan proses kegiatan pembelajaran pertanian budidaya hortikultura dapat dijelaskan sebagai berikut. Kegiatan pertama, mengitung jumlah biji yang dibutuhkan, disesuaikan dengan tempat tanam (pot atau lahan) yang ada. Bagi siswa berkebutuhan khusus tunagrahita, pekerjaan menjimpit satu biji demi satu biji merupakan proses pengembangan sensomotorik yang sangat penting. Siswa juga belajar melafal angka sesuai jumlah biji yang dihitung. Pada saat menghitung biji, siswa juga melatih rabaan untuk membedakan lunak-keras, halus- kasar. Biji yang sudah dihitung dimasukkan ke dalam plastik dengan jumlah 5 atau 10 biji per plastik. Kegiatan selanjutnya menanam adalah merawat biji yang ditanam di pralon atau gelas plastik 
bekas minuman, atau polibag. Pralon di gunakan sebagai pot untuk menanan tanaman sayur berakar pendek seperti kangkung dan caysim. Gelas plastik bekas minuman digunakan untuk menyemai biji cabe dan terong, sampai umur 1 bulan, kemudian bibit cabe/terong dipindah ke tanah kebun. Untuk memudahkan pengamatan, dilakukan pemberian nomor pada gelas plastik. Proses pemberian label nomor merupakan latihan menulis yang menyenangkan terutama bagi siswa tuna grahita. Memasukkan tanah dan biji ke dalam gelas bekas merupakan latihan sensomotorik anak tunagrahita. Setiap pekan siswa mengamati pertumbuhan biji sampai panen.

Hasil penelitian Septiana et al (2015: 1), menyimpulkan pembelajaran biologi saat ini identik dengan hafalan, terlebih pada klasifikasi tumbuhan, dimana siswa diminta untuk mengetahui ciri-ciri tumbuhan secara serta mengelompokkannya berdasarkan ciri-ciri tersebut. Keadaan ini dapat menyebabkan siswa memiliki beban kognitif tinggi sebagai dampak dari kurangnya pengalaman siswa yang berhubungan dengan tumbuhan. Program keterampilan pertanian ini menjadi alternatif pembelajaran yang mengurangi beban kognitif dimana siswa belajar secara nyata mengamati pertumbuhan tanaman, belajar konkrit bagian tumbuhan secara lengkap dari biji, akar, batang, daun, bunga, buah, dan menanam bijinya kembali, merawat tanaman supaya tumbuh subur dan mengetahui siklus hidup tumbuhan. Membandingkan bahwa tiap tumbuhan mempunyai ciri khas daun, bunga dan buah (spesifikasi), yang bermanfaat untuk pengembangan aspek kognitif.

Menurut Mayangsari (2004: 5), kemampuan mengenal warna merupakan salah satu lingkup perkembangan kognitif yang harus dikuasai anak. Pengenalan warna bagi anak dapat merangsang indera penglihat, otak dan estetika. Indera penglihat merupakan mediator antara dunia nyata dan otak. Persepsi visual tergantung pada interpretasi otak terhadap suatu rangsangan yang diterima oleh mata. Salah satu faktor pembangun imajenasi dan kreativitas anak adalah aspek warna. Anak dapat mengoptimalkan pengenalan warna selama kegiatan pembelajaran keterampilan pertanian. Adanya berbagai tanaman di kebun menjadi sarana yang efektif bagi pengembangan kognitif tuna grahita. Mereka bisa mengenal aneka warna melalui perubahan warna buah cabe dari hijau, kuning, sampai merah dan siap panen.

Yuliani (2004 : 14) menuliskan tentang teori kognitif Ausubel yang mengatakan tentang belajar bermakna yang merupakan proses mengaitkan informasi suatu materi baru dengan konsep-konsep yang telah ada dalam struktur kognitif. Dari teori tersebut dapat dipahami bahwa pembelajaran konsep waktu adalah belajar bermakna yang disertai pengertian bukan cuma hafalan. Pekerjaan di kebun organik seperti menyiram tanaman, menyiangi gulma, mengolah tanah dengan mencampurnya dengan kompos, memerlukan pengaturan waktu yang tepat, sehingga siswa mengenal langsung konsep waktu seperti nama hari, jam, konsep pagisiang-sore untuk melakuakn perawatan budidaya organik hortikultura.

Clements, Wilson, \& Sarama (dalam Seefeldt \& Wasik, 2008:398) menyatakan: "Membangun konsep geometri pada anak dimulai dengan mengidentifikasi bentuk-bentuk, menyelidiki bangunan, memisahkan gambargambar biasa, seperti segitiga, segiempat, lingkaran." Dalam mengenalkan konsep geometri pada siswa tunagrahita, diperlukan suatu metode pembelajaran yang sesuai agar dapat dipahami dan dimengerti oleh siswa tunagrahita. Salah satu metode pembelajaran yang dapat digunakan guru dalam mengenalkan konsep geometri yaitu melalui kegiatan pembelajaran keterampilan pertanian. Benda, alat, bahan yang ada di lingkungan pertanian juga dijadikan sarana pengenalan bentuk geometri sederhana seperti ember, gelas plastik dan gayung berbentuk tabung, tomat ada yang tabung dan bulat. Kotak kayu persemaian biji berbentuk kubus.

J.Tombokan Runtukahu dan Selpius Kandou (2014: 13), menyebutkan tahap menghitung adalah pertama tahap konsep atau pengertian, yaitu pemahaman atau pengertian tentang sesuatu dengan menggunakan benda konkret seperti pengenalan warna, bentuk dan menghitung dengan kegiatan, kegiatan tersebut dilakukan dengan menarik dan dapat dipahami oleh anak. Kedua adalan tahapan transisi atau peralihan yaitu peralihan dari konkrit ke abstrak dari konsep lambang bilangan. Tahap ini adalah saat anak benar-benar memahami konsep dengan cara apa saja. Ketiga tahap lambang bilangan pada tahapan ini anak sudah diberi kesempatan menuliskan lambang bilangan sendiri tanpa paksaan. Guru berperan aktif untuk 
menunjukan dengan cara memfariasikan metode menghitung melalui benda konkrit dengan media pertanian yang dikemas dengan begitu menarik sehingga anak menyukainya dan pembelajaran menjadi menyenangkan. Missal lambang bilangan 5 untuk menggambarkan jumlah bilangan 5 pada plastik penyimpan biji dan penomoran pada gelas pot. Biji-bijian dikelompokkan menurut jumlahnya $5,10,15$, dst.

Menurut Hallahan (2009: 149), keterbatasan kognitif yang dialami anak tunagrahita akan berdampak juga pada tingkat kemampuan anak dalam menyesuaikan diri terhadap lingkungan sekitarnya. Hasil penelitian Edward A. Polloway, James R. Patton, and Marvalin A (2011:181) menyebutkan, implikasi dari keterbatasan/ hambatan belajar tersebut, bahwa dalam pengajaran/pendidikan anak tunagrahita diperlukan contoh konkret, pengalaman belajar kontekstual, serta mendorong interaksi aktif antara siswa dan lingkungan. Karakteristik tunagrahita yang lemah dalam berpikir abstrak dan terbatas perkembangan kognitifnya perlu suatu pendekatan pembelajaran. Pembelajaran keterampilan pertanian budidaya hortikultura ini bertujuan untuk menstimulasi dalam mengoptimalkan kemampuan kognitif dan melatih keterampilan vokasional tunagrahita serta dirancang sesuai dengan karakteristik dan prinsip pembelajarannya.

Materi disajikan dari yang mudah ke yang sukar, dari yang sederhana ke yang kompleks dan dari yang konkret ke yang abstrak. Pembelajaran keterampilan pertanian budidaya hortikultura menyediakan media pembelajaran yang konkrit seperti berbagai tanaman sayuran untuk mengenal tumbuhan, mulai dari biji, proses pertumbuhannya, dan bagian-bagian tumbuhan. Proses pembelajaran pertanian mengaktifkan langsung kognitif siswa dengan belajar berhitung, menulis, dan membaca menggunakan media alat-alat dan bahan pertanian seperti biji, daun dan buah. Siswa belajar menerapkan pengukuran waktu dan membaca kalender.

Siswa tunagrahita ringan memerlukan layanan pendidikan yang mengoptimalkan kognitifnya melalui pembelajaran yang konkrit, sesuai dengan tahap perkembangannya, sekaligus juga melatih keterampilan vokasionalnya. Pembelajaran keterampilan pertanian budidaya hortikultura menjadi alternatif pembelajaran yang konkrit yang masih perlu penelitian dan pengembangan lebih lanjut untuk optimalisasi kognitif dan melatih keterampilan vokasional bidang pertanian untuk melatih kemandirian tunagrahita.

\section{KESIMPULAN DAN SARAN}

Berdasarkan hasil penyajian data dan pembahasan dapat disimpulkan bahwa kemampuan kognitif ini penting untuk merespon lingkungan sekitarnya termasuk dalam kegiatan keterampilan budidaya hortikultura. Anak tunagrahita ringan masih memerlukan penguatan optimalisasi kognitif untuk mendukung kemampuan vokasionalnya. Untuk dapat meningkatkan kemampuan kognitif maka diperlukan berbagai aktivitas yang dapat mendorong anak untuk berlatih mengoptimalkan kemampuan kognitifnya.

Kesimpulan dari hasil penelitian aktifitas budidaya holtikultura anak tunagrahita ringan memiliki kemampuan kognitif yang lengkap untuk konsep sains sederhana. Kemampuan kognitif belum lengkap dengan skor 6 pada pengetahuan bentuk geometri, pengetahuan ukuran baku/tidak baku dan pengetahuan konsep waktu, skor 5 pada kemampuan mengenal benda di sekitarnya, skor 4 pada konsep bilangan 0-50 dan kemampuan menyelesaikan masalah sederhana. Skor terendah pada kemampuan pengetahuan konsep urutan dengan skor 2 (belum memiliki kemampuan kognitif pada aspek tersebut). Dapat disimpulkan bahwa siswa tunagrahita ringan masih memerlukan penguatan untuk mendapatkan aspek kognitif yang optimal sebagai pendukung aktivitas keterampilam pertanian budidaya hortikultura.

\subsection{Saran}

1. Bagi guru, menyediakan program pembelajaran yang dapat mengoptimalkan dan melatih kemampuan kognitif siswa tunagrahita

2. Bagi sekolah, merencanakan dan menyusun program pendidikan vokasional pertanian budidaya hortikultura bagi siswa tunagrahita yang dapat mengoptimalkan dan melatih kemampuan kognitifnya

3. Bagi orang tua, melatih kemampuan kognitif di rumah sehingga terjadi integrasi 
pendidikan di rumah dan di sekolah dengan baik.

4. Bagi peneliti, dapat melakukan penelitian lebih lanjut tentang berbagai keterampilan vokasional yang sekaligus mengoptimalkan kemampuan kognitif untuk bekal kemandirian yang lebih baik.

\section{UCAPAN TERIMA KASIH}

Peneliti mengucapkan terima kasih kepada SLB Wiyata Dharma 1 Sleman dan semua pihak atas izin yang diberikan untuk melakukan penelitian dan memberikan dukungan serta sarannya sehingga penelitian ini dapat berjalan dengan baik

\section{DAFTAR RUJUKAN}

Abdurrahman, M. (2003). Pendidikan Bagi Anak Berkesulitan Belajar. Jakarta: PT. Rineka Cipta.

Alimin, Z (2006). Model Pembelajaran Anak Tunagrahita Melalui Pendekatan Konseling, Penelitian Tindakan Kolaboratif dalam Upaya Mengembangkan Anak Tunagrahita Mencapai Perkembangan Optimum. Disertasi Sekolah Pascasarjana UPI: Bandung.

Astati. 2001. Persiapan Pekerjaan Penyandang Tunagrahita. Bandung: CV. Pandawa

Ayres, K. M., Mechling, L \& Sansosti, F.J. (2013). The Use Of Mobile Technologies To Assist With Life Skills/Independence of Students With Moderate/SevereIntellectual Disability And/Or Autism Spectrum Disorders: Considerations ForThe Future Of School Psychology. Jurnal Psikologi, Vol. 50(3), Diakses dariwileyonlinelibrary.com/journal/pits.

Borg, Walter R. \& Gall Meridith Damien (2007). Educationa Research. Six edition. New York: Longman

Dunn, John.M \& Leitschuh, Carol.A. 2014. Special Physical Education. Lowa: Kendall / Hunt Publishing Company

Direktur Statistik Kesejahteraan Rakyat - Badan Pusat Statistik - SUSENAS, 14 Desember 2016

Eldevik, S., Jahr, E., Eikeseth, S., Hastings, R., \& Hughes, C. 2010. Cognitive and

\begin{abstract}
Adaptive Behavior Outcomes of Behavioral Intervention for Young Children With Intellectual Disability. Behavior Modification, 34(1), 16. Retrieved June 11, 2010, from ProQuest Education Journals. (Document ID: 1943253901).
\end{abstract}

Een Ratnengsih, 2017. Implementasi Program Vokasional bagi Anak Tunagrahita ejournal.upi.edu/index.php/jassi/article/do wnload/7663/4934

Hallahan, DP. \& Kauffman, JM. 2003. Exceptional Learner:Introduction to Special Education. Boston: Pearson Education, Inc.

Hallahan, D.P., Kauffman, J.M. \&Pullen, P.C. (2009). Exceptional Learners. America: Pearson Education.

Ira Ariyanti, Juang Sunanto, Ahmad Nawawi (2015). Kegiatan Pembelajaran Bertani Pada Siswa Tunanetra di SLB Agro Industri Cisarua Kabupaten Bandung Barat. Jurnal Pedagogia.

J.Tombokan Runtukahu dan Selpius Kandou (2014). Pembelajarn Matematika Dasar Bagi Anak Berkesulitan Belajar. Yogyakarta:Ar-Ruz Media

Kementerian Pendidikan dan Kebudayaan (2014). Kurikulum 2013. Pedoman Pelaksanaan Bagi Peserta Didik Berkebutuhan Khusus. Jakarta : Direktorat Pendidkan Khusus dan Layanan Khusus.

Mayangsari, Sriti. 2004. Peran Warna terhadap Perkembangan dan Pendidikan Anak di Taman Kanak-kanak. Jurnal Dimensi Interior Vol.2 No1. Jakarta.

Mumpuniarti (2007). Pembelajaran Akademik Bagi Tunagrahita. Yogyakarta: FIP UNY.

Nurmala, dkk (2012). Pengantar Ilmu Prtanian. Yogyakarta: Graha Ilmu

Polloway Edward A \& Patton James R. 1993. Strategies For Teaching Learners With SpecialNeeds. USA . Macmillan Publishing Company

Seefeldt, Carol \& Wasik, A Barbara. (2008). Pendidikan Anak Usia Dini: Menyiapkan Anak Usia Tiga, Empat, dan Lima Tahun Masuk Sekolah. (Penterjemah: Pius Nasar). Jakarta: PT INDEKS.

Septiana et al (2015). Framing pada Klasifikasi Tumbuhan untuk Menurunkan Beban Kognitif. Makalah Seminar Nasional XII Pendidikan Biologi FKIP UNS. 
Schalock, R. L., Borthwick-Duffy, S. A., Bradley, V. M., Buntinx, W. H. E., Coulter, D. L., Craig, E. M., ... Yeager, M. H. (2010). Intellectualdisability: Definition, classification, and systems of supports. Washington, DC: American Association on Intellectual and Developmental Disabilities.

Smith, M. B., Ittenbach, R. F. \& Patton, J.R ( 2002). Mental retardation. 6th ed. New Jersey: Merrill Prentice Hall.

Sugiyartun (2009). Pendidikan Tunagrahita. Bandung: Rosda Karya

Sugiyono (2013). Metode Penelitian Kuantitatif, Kualitatif Dan R\&D. Cetakan Ke-19. Bandung: Alfabeta

Wina Sanjaya (2013). Penelitian Pendidikan: Jenis, Metode, dan Prosedur. Jakarta: Prenadamedia Group

Yeung EH, Sundaram R, Bell EM, Druschel C, Kus C, Ghassabian A, Bello S, Yunlong $\mathrm{X}$, and Louis GB. (2016). Examining Infertility Treatment and Early Childhood Development in the Upstate KIDS Study. JAMA Pediatrics

Yuliani, dkk (2004). Metode Pengembangan Kognitif. Jakarta : Universitas Terbuka 